A Process Philosophy of Signs 



\section{A Process Philosophy of Signs}

James Williams 
(C) James Williams, 2016

Edinburgh University Press Ltd

The Tun - Holyrood Road,

12(2f) Jackson's Entry,

Edinburgh EH8 8PJ

www.euppublishing.com

Typeset in I I/I 3 Adobe Sabon by IDSUK (DataConnection) Ltd, and printed and bound in Great Britain by CPI Group (UK) Ltd, Croydon CR0 4YY

A CIP record for this book is available from the British Library

ISBN 9780748695003 (hardback)

ISBN 9780748695027 (webready PDF)

ISBN 9780748695010 (paperback)

ISBN 9780748695034 (epub)

The right of James Williams to be identified as the author of this work has been asserted in accordance with the Copyright, Designs and Patents Act 1988, and the Copyright and Related Rights Regulations 2003 (SI No. 2498). 